\title{
Hydrodynamic performance of a three-phase airlift bioreactor with an enlarged degassing zone
}

\author{
A.A. Vicente, J.A. Teixeira
}

Abstract The hydrodynamics of biotechnological processes is complex. So far, few studies were made with bioreactors of the airlift type with an enlarged degassing zone.

In this work, the influence of solids loading, solids specific gravity and draught tube dimensions on mixing and circulation times and critical air flow rate for an internal loop airlift bioreactor with an enlarged sedimentation/degassing zone is studied.

The results indicate that the critical air flow rate as well as the mixing time increase with an increase in solids loading in the bioreactor. Circulation time presents a maximum for a solids load between 5 and $10 \%(\mathrm{v} / \mathrm{v})$. It is also shown that small variations in solids specific gravity, for values close to that of the liquid, have a significant influence on the critical air flow rate and on the mixing time.

An optimal (minimal) value for the circulation time and for the critical air flow rate was obtained for a riser to down comer diameter ratio of 0.46 . The minimum mixing time was obtained for a riser to down comer height ratio of 0.80 .

1

\section{Introduction}

During the last decade, the airlift as a bioreactor became more and more important. Starting from the production of single-cell protein, now in decline, it has been used for the most various processes, such as waste waters biological treatment, antibiotics, animal and vegetable cell production [1], [2], [3], [4].

Part of the success is, surely, due to its peculiar characteristics, namely the approximately constant and low shear that it generates in the medium (being, therefore, ideal for those cultures less resistant to mechanical damage) [5], [6], [7], its simpler design (easier to build and less prone to contamination), its ease of operation and its need for smaller investments and lower maintenance costs [3], [8], [9]. It is known,

Received 11 April 1995

A.A. Vicente, J.A. Teixeira

Departamento de Engenharia Biológica, Universidade do Minho, 4709 Braga Codex, Portugal

Correspondence to: J.A. Teixeira

This work was supported by J.N.I.C.T. (Junta Nacional de Investigação Científica e Tecnológica). however, to have a lower oxygen mass transfer coefficient, which is generally attributed to the absence of mechanical agitation, when compared to other types of reactor.

Until the present moment, only a few studies were made on internal draught tube airlift bioreactors having a significantly enlarged gas-liquid separator [5], [10], [11], [12], [13] and, of these, none was concerned with three-phase bioreactors.

Also, only one paper has been published, up till now, where the critical gas velocity at stalling was determined [14], together with the liquid re-circulation velocity, for several particle loading. The particles were glass beads, with mean diameters ranging from $0.0975 \mathrm{~mm}$ to $1.130 \mathrm{~mm}$ and a specific gravity of $2950 \mathrm{~kg} / \mathrm{m}^{3}$.

The influence of the specific gravity $\left(907 \mathrm{~kg} / \mathrm{m}^{3}, 1250 \mathrm{~kg} / \mathrm{m}^{3}\right.$, $1420 \mathrm{~kg} / \mathrm{m}^{3}$ and $1470 \mathrm{~kg} / \mathrm{m}^{3}$ ) of the solid phase was studied by Siegel et al. [15], but for a rectangular airlift reactor.

P. Weiland [16] suggested that a diameter ratio between 0.8 and 0.9 is recommended to achieve high oxygen mass transfer and efficient mixing. Nevertheless, the same author states that, in case of a three-phase reactor, a ratio of 0.6 should be used, to prevent sedimentation of the solid particles.

The hydrodynamic performance in terms of mixing time and circulation time of the liquid phase can be determined using a $\mathrm{pH}$ pulse technique, which has already been widely discussed [17], [18], [19], [20], [21]. This technique is usually preferred in place of optical density and conductivity methods.

Biotechnological processes are complex in hydrodynamic and mass and heat transfer terms. This complexity results from the number of phases in the bioreactor, often 3 or 4 , one of which is usually a solid immobilised biocatalyst.

In natural or artificial immobilised cell systems, the most common phase combination is gas-liquid-solid. Solids loading may be as high as 30 or $40 \%$ of the total volume of the bioreactor. Although with some associated problems (low mechanical resistance, leakage of viable cells, internal mass transfer resistance [22] ), the fact is that Ca-alginate is a widely used matrix for the entrapment of enzymes and biomass in continuous fermentation, in order to achieve higher productivity. An interesting alternative technique is the utilisation of flocculating cultures. Sousa et al. [3] reported the utilisation of a continuously operating airlift bioreactor with a decelerating zone for ethanol production using a flocculating yeast.

In many immobilised cell systems, the specific gravity of the solid particles in suspension (immobilised biomass in immobilisation support) lies in values close to $1000 \mathrm{~kg} / \mathrm{m}^{3}$. Moreover, as cell growth occurs small changes in particles' specific gravity are also expected to take place. 
The aim of the present work is to study the influence of solids loading $(5,10,15$ and $20 \%(\mathrm{v} / \mathrm{v}))$ and solids specific gravity (values close to $1000 \mathrm{~kg} / \mathrm{m}^{3}$ ) in the mixing and circulation times and in the critical air flow rate (i.e., the minimum airflow rate that is needed to keep the solids circulating in the reactor), for a 5.51 internal loop airlift bioreactor, with an enlarged degassing zone. This effect is studied for several riser to down comer diameter and height ratios, leading to an optimisation of the reactor design in terms of these parameters.

\section{2}

\section{Materials and methods}

\section{1}

\section{The reactor}

The reactor used is shown in Fig. 1. It was of the concentric draught tube type, made of plexiglas, with a total height of $0.9 \mathrm{~m}$, a down comer with $0.6 \mathrm{~m}$ of height and an inside diameter of $0.07 \mathrm{~m}$. The reactor was filled with liquid up to the height of $0.76 \mathrm{~m}$. The draught tube's heights and diameters are shown in Table 1. The thickness of the draught tube was $0.04 \mathrm{~m}$ and its bottom edge was $0.03 \mathrm{~m}$ above the bottom of the reactor.

The air injection was made immediately below the annulus of the riser by means of a nozzle injector with a diameter of $1 \mathrm{~mm}$.

The top section was of the cylindrical conical type to facilitate the degassing and the solids' deceleration. The angle

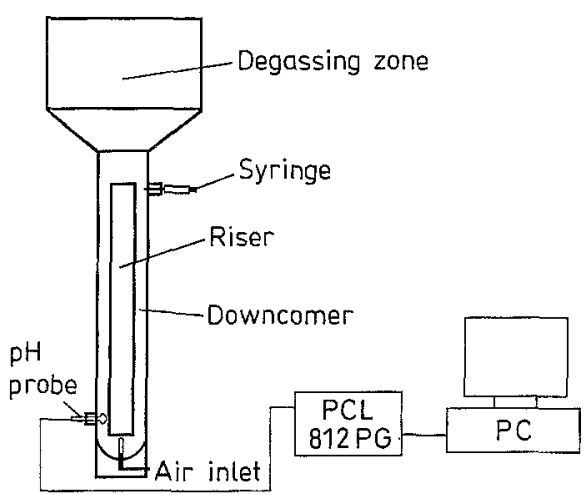

Fig. 1. Schematic diagram of the experimental set-up

Table 1. Draught tube's height and diameters as used in the experiments

\begin{tabular}{|c|c|c|c|c|c|c|c|c|c|}
\hline $\begin{array}{l}\text { Draught } \\
\text { tube nr. }\end{array}$ & 1 & 2 & 3 & 4 & 5 & 6 & 7 & 8 & 9 \\
\hline $\begin{array}{l}\text { Draught } \\
\text { tube } \\
\text { diameter } \\
\text { Dr }(\mathrm{m})\end{array}$ & 0.022 & 0.032 & 0.044 & 0.022 & 0.032 & 0.044 & 0.022 & 0.032 & 0.044 \\
\hline $\begin{array}{l}\text { Draught } \\
\text { tube } \\
\text { height } \\
\mathrm{Hr}(\mathrm{m})\end{array}$ & 0.42 & 0.42 & 0.42 & 0.48 & 0.48 & 0.48 & 0.56 & 0.56 & 0.56 \\
\hline
\end{tabular}

of the conical sector with the main body of the reactor was of $51^{\circ}$ and the height and diameter of the cylindrical part were, respectively, $0.145 \mathrm{~m}$ and $0.192 \mathrm{~m}$.

\section{2}

\section{Ca-alginate beads}

The Ca-alginate beads were obtained dissolving $2 \%(\mathrm{w} / \mathrm{v})$ alginate (Manutex RSX, from Kelco International, Ltd.) in water heated up to $70^{\circ} \mathrm{C}$. After cooling, the alginate solution was pumped by means of a peristaltic pump (Ismatec MS-Reglo from Ismatec, Switzerland) through nozzles of $1 \mathrm{~mm}$ diameter, dropping to a $2 \%(\mathrm{w} / \mathrm{w})$ calcium chloride solution.

To increase the specific gravity of the beads, $20 \%(\mathrm{w} / \mathrm{v})$ compressed baker's yeast was added. It was dispersed in water and, after a heat treatment to kill the cells $\left(1800 \mathrm{~s}, 50^{\circ} \mathrm{C}\right)$, the alginate was dissolved in the mixture.

The mean diameter and specific gravity of the beads without cells (from now on referred to as "lower specific gravity beads" or LB) were $2.092 \pm 0.003 \mathrm{~mm}$ and $1016 \pm 1 \mathrm{~kg} / \mathrm{m}^{3}$, respectively, and the values for the beads with immobilised cells (from now on referred to as "higher specific gravity beads" or $\mathrm{HB}$ ) were $2.086 \pm 0.003 \mathrm{~mm}$ and $1048 \pm 1 \mathrm{~kg} / \mathrm{m}^{3}$. At the end of the all sets of experiments, the values had a slight change to $2.174 \pm 0.003 \mathrm{~mm}$ and $1010 \pm 1 \mathrm{~kg} / \mathrm{m}^{3}$, for the first case, and $2.224 \pm 0.003 \mathrm{~mm}$ and $1047 \pm 1 \mathrm{~kg} / \mathrm{m}^{3}$, for the second.

\section{3}

\section{Determination of the critical air flow rate}

The critical air flow rate is the one needed to prevent the reactor from stalling. This value was determined for $5,10,15$ and $20 \%(\mathrm{v} / \mathrm{v})$ solids loading, with and without yeast cells, for each of the draught tubes characterised in Table 1.

\section{4}

\section{Liquid mixing determinations}

To determine the circulation and mixing times, the $\mathrm{pH}$ pulse technique was used. The $\mathrm{pH}$ was first lowered to a value around 3 with sulphuric acid and, after stabilisation, a pulse of $5 \mathrm{~mm}^{3}$ sodium hydroxide solution $\left(0.5 \mathrm{mmole} / \mathrm{m}^{3}\right)$ was injected in the reactor at time zero. The data acquisition was stopped once a constant $\mathrm{pH}$ value was obtained. In order to minimise the alginate beads' turgescence, the reactor was emptied and the alginate beads were washed after each experiment. Three replicates were made for each set of experimental conditions.

The $\mathrm{pH}$ measurement system (Metrohm $691 \mathrm{pH}$ meter, Switzerland) was coupled to a data acquisition system (PCL-812PG Enhanced Multi-Lab Card, Advantech Co, Ltd.), which transmitted the signal to a personal computer. The $\mathrm{pH}$ sensor was located $0.04 \mathrm{~m}$ above the bottom of the reactor (Fig. 1).

The base injection was made with a syringe, $0.41 \mathrm{~m}$ above the bottom of the reactor (Fig. 1). Some preliminary studies were made in order to determine the best location for the placement of the electrode and for the injection site. Typical $\mathrm{pH}$ response curves are shown in Fig. 2. Determinations were made for $0,5,10,15$ and $20 \%(\mathrm{v} / \mathrm{v})$ solids loading, for each of the draught tubes characterised in Table 1, except for those of larger diameters. 


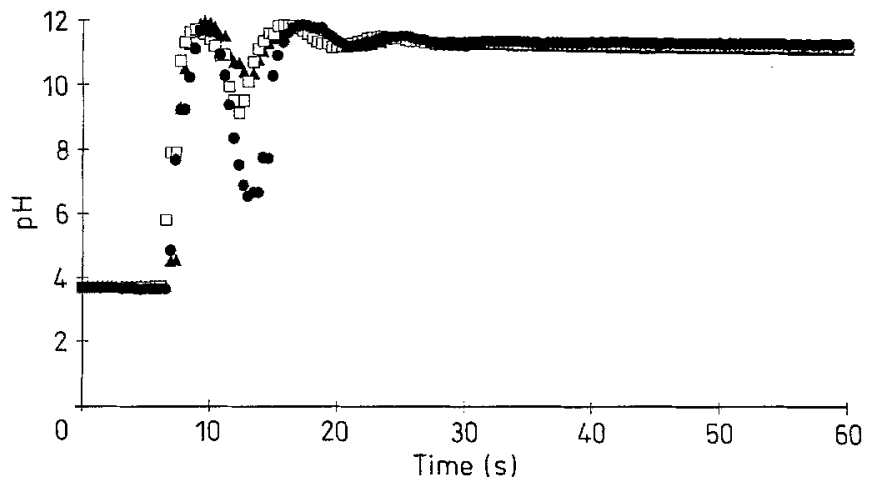

Fig. 2. Typical $\mathrm{pH}$ response curves

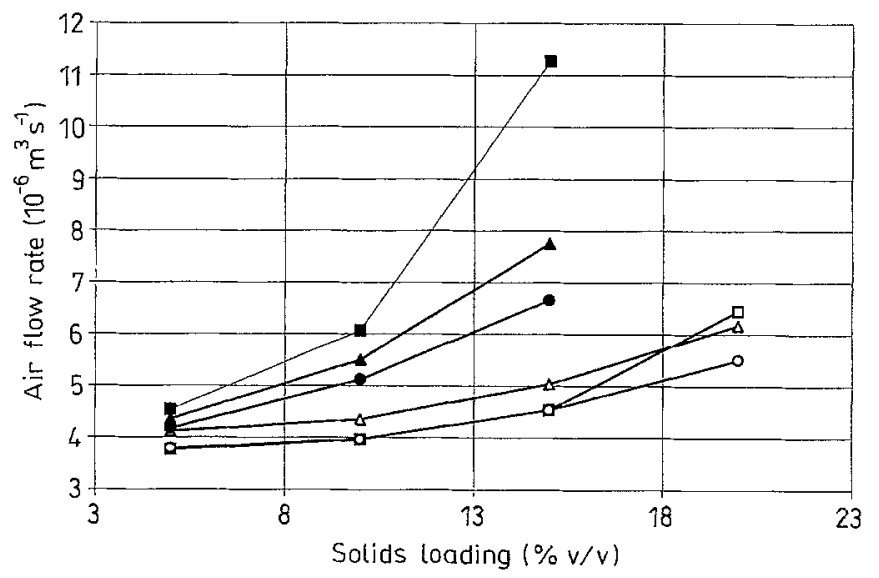

Fig. 3. Critical air flow rates vs. the solids loading for the draught tubes with a diameter of $0.022 \mathrm{~m}$ and different heights, for the lower and higher specific gravity beads. ( $\square-\mathrm{Hr}=0.42 \mathrm{~m}, \mathrm{LB} ; \triangle-\mathrm{Hr}=0.48 \mathrm{~m}, \mathrm{LB}$; $\mathrm{O}-\mathrm{Hr}=0.56 \mathrm{~m}, \mathrm{LB} ; \boldsymbol{\square}-\mathrm{Hr}=0.42 \mathrm{~m}, \mathrm{HB} ; \boldsymbol{\Lambda}-\mathrm{Hr}=0.48 \mathrm{~m}, \mathrm{HB}$; - $\mathrm{Hr}=0.56 \mathrm{~m}, \mathrm{HB}$ )

\section{3}

\section{Results and discussion}

\section{1}

\section{Critical air flow rate}

Figure 3 shows the effect of the draught tube height and the beads' specific gravity on the critical air flow rate, for the smaller diameter draught tubes. It is clear that, as expected, the higher specific gravity beads need higher air flow rates to keep on circulating even with specific gravity differences as small as the ones used in these experiments; this effect is more evident with the small height draught tube. In this case, and with a density difference of $4 \%$, a two fold increase in the critical air flow rate is observed with the solids load of $15 \%$. Furthermore, an increase of the critical air flow rate with the increase of the solids loading can be detected for all the tubes. Also, the critical air flow rate increases with the decrease of the height of the draught tube.

This is not unexpected once, for the same diameter and the same air flow rate, the liquid velocity in the draught tube increases with the draught tube's height [18]. As the liquid velocity, in turn, increases with the air flow rate [18], this

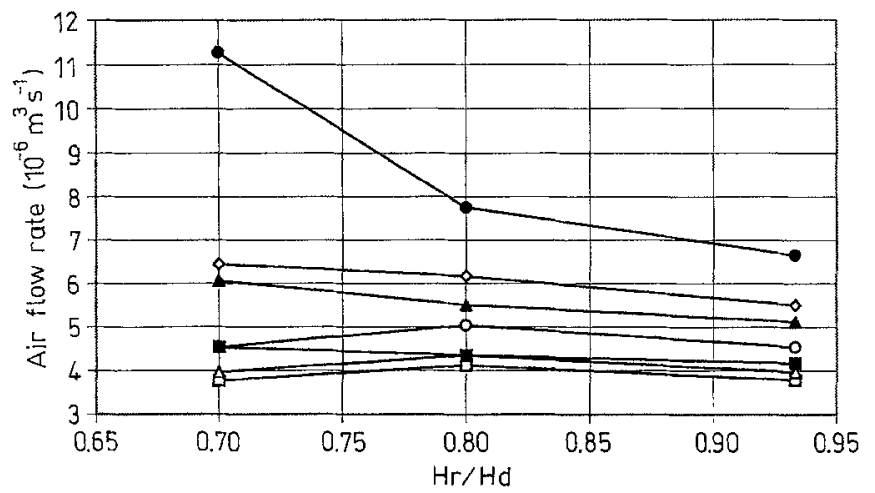

Fig. 4. Critical air flow rates vs. the riser to down comer height ratio $(\mathrm{Hr} / \mathrm{Hd})$ for the draught tubes with a diameter of $0.022 \mathrm{~m}$, with different solids loading, for the lower and higher specific gravity beads. $\square-5 \%$ solids, LB; $\triangle-10 \%$ solids, LB; $\bigcirc-15 \%$ solids, LB; $\diamond-20 \%$ solids, LB; $-5 \%$ solids, $\mathrm{HB}$; $-10 \%$ solids, $\mathrm{HB} ;-15 \%$ solids, $\mathrm{HB}$ )

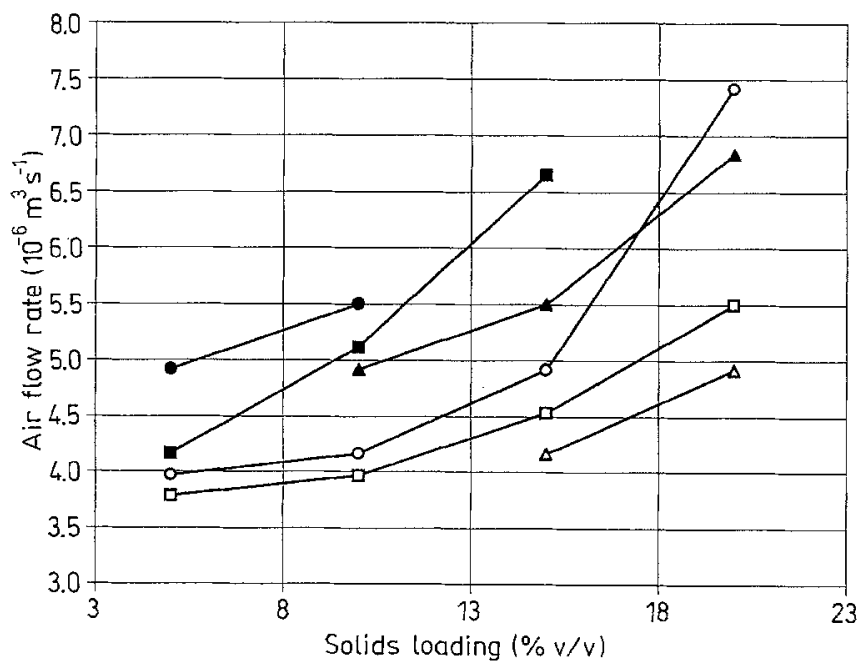

Fig. 5. Critical air flow rates vs. the solids loading for the draught tubes with a height of $0.56 \mathrm{~m}$ and different diameters, for the lower and higher specific gravity beads. $(\square-\mathrm{Dr}=0.022 \mathrm{~m}, \mathrm{LB} ; \triangle-\mathrm{Dr}=0.032 \mathrm{~m}, \mathrm{LB}$; $-\mathrm{Dr}=0.044 \mathrm{~m}, \mathrm{LB} ; \boldsymbol{\square}-\mathrm{Dr}=0.022 \mathrm{~m}, \mathrm{HB} ; \boldsymbol{A}-\mathrm{Dr}=0.032 \mathrm{~m}, \mathrm{HB}$; - $\mathrm{Dr}=0.044 \mathrm{~m}, \mathrm{HB}$ )

means that to keep the solids circulating in successively higher draught tubes, decreasing air flow rates are needed.

The same behaviour was obtained for the draught tubes with intermediate diameter. Nevertheless, with the larger diameter draught tubes, the circulation of the higher specific gravity beads was practically impossible, due to the accumulation of the particles in the bottom of the reactor and in the down comer, caused by the narrow space between the down comer and the riser walls. Fig. 4 confirms the above results: For draught tubes with the same diameter, there is a lowering of the critical air flow rate with the increase of the riser to down comer height ratio.

Figure 5 shows the results, in terms of critical air flow rates, for the larger height draught tube with different diameters. Once again, the higher specific gravity beads needed higher air flow rates to circulate. There is a difference, however, relatively to the previous case: The order of appearance of the curves, namely the larger diameters (as, before, the larger heights) 


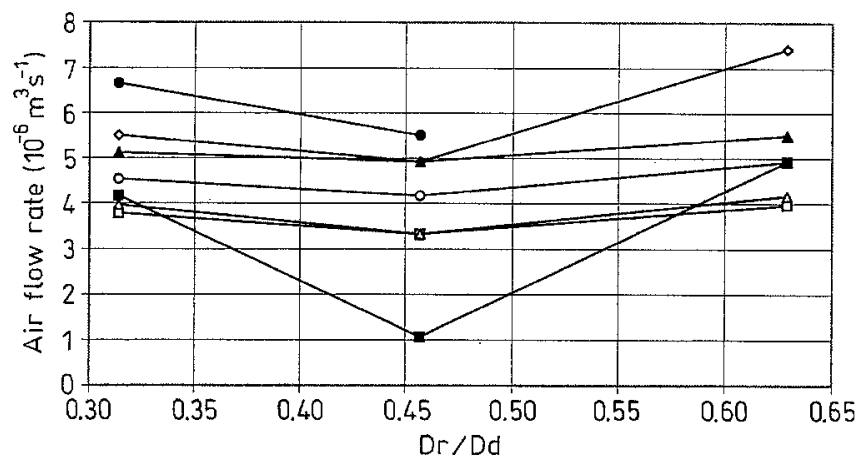

Fig. 6. Critical air flow rates vs. the riser to down comer diameter ratio (Dr/Dd) for the draught tubes with a height of $0.56 \mathrm{~m}$, with different solids loading, for the lower and higher specific gravity beads. ( $\square-5 \%$ solids, LB; $\triangle-10 \%$ solids, $L B ; O-15 \%$ solids, $L B ; \diamond-20 \%$ solids, LB; $-5 \%$ solids, $\mathrm{HB} ; \boldsymbol{\Delta}-10 \%$ solids, $\mathrm{HB} ;-15 \%$ solids, $\mathrm{HB}$ )

need lower air flows to keep the circulation of the solid phase, is altered; now, the larger diameter draught tubes seem to make the solids circulation more difficult. This is clearly seen in Fig. 6, where a riser to down comer diameter ratio of around 0.46 appears to be the best, if the aim is to minimise the air flow rate needed. The other draught tube heights showed an identical behaviour.

\section{2}

\section{Circulation time}

As shown in Figs. 7 and 8, the specific density of the beads seems to have only a slight influence on the circulation time. More important is the influence of the solids loading, which makes the circulation time to increase till it reaches a maximum between 5 and $10 \%(\mathrm{v} / \mathrm{v})$ of solids, for the draught tubes with smaller diameters and for the draught tubes with smaller heights; for the other tubes, this observation is not so evident, the values of circulation time being practically constant throughout the solids loading range in analysis.

The circulation time, however, clearly increases with the height of the draught tube (see Fig. 9). Although, for a given diameter, the liquid velocity is higher for the higher draught tube [18], the liquid has to cover a larger distance, and this seems to have a strong influence in the results. Also the influence of the enlarged top section should not be neglected: with the smaller height draught tubes (that have their upper edge much below the conical enlargement), the top section may behave like a stagnant zone, meaning that the presented circulation values refer, mainly, to the flow in the riser/down comer zone. For the larger height draught tubes the liquid leaving the tube is injected right into the bottom of the enlarged zone where it will circulate, being the obtained circulation times, therefore, a more realistic approach to the circuation times in the bioreactor.

The larger diameter draught tubes were not analysed with respect to this parameter and the one discussed in the next section (mixing time), because the circulation of the solid phase was difficult or non-existent. Even so, it is noteworthy to say that with the reactor stalled, it was still possible to detect liquid circulation, although with circulation and mixing times completely out of the range obtained in the other experiments.

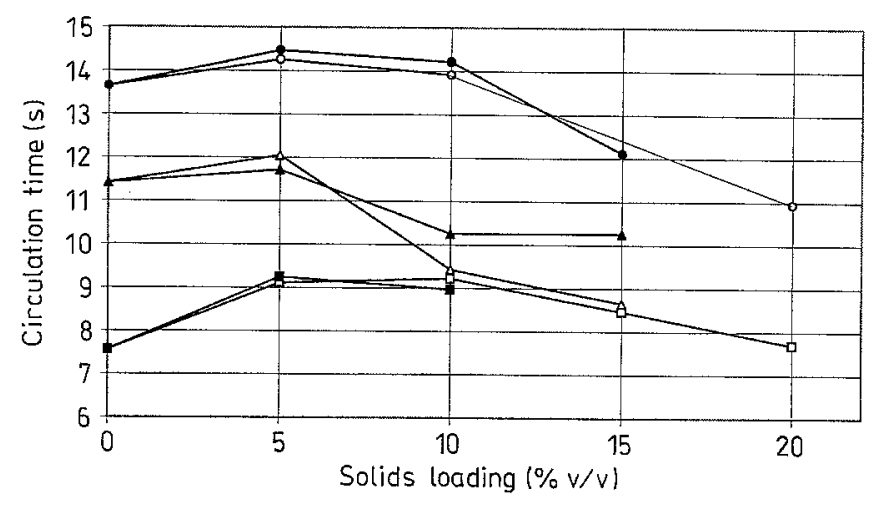

Fig. 7. Circulation time vs. solids loading for the draught tubes with a diameter of $0.022 \mathrm{~m}$ and with different heights, for the lower and higher specific gravity beads, with an air flow rate of $1.23 \mathrm{E}-5 \mathrm{~m}^{3} / \mathrm{s}$. ( $\square$ $-\mathrm{Hr}=0.42 \mathrm{~m}, \mathrm{LB} ; \triangle-\mathrm{Hr}=0.48 \mathrm{~m}, \mathrm{LB} ; \mathrm{O}-\mathrm{Hr}=0.56 \mathrm{~m}, \mathrm{LB}$; - $\mathrm{Hr}=0.42 \mathrm{~m}, \mathrm{HB} ; \boldsymbol{\Delta}-\mathrm{Hr}=0.48 \mathrm{~m}, \mathrm{HB} ;-\mathrm{Hr}=0.56 \mathrm{~m}, \mathrm{HB})$

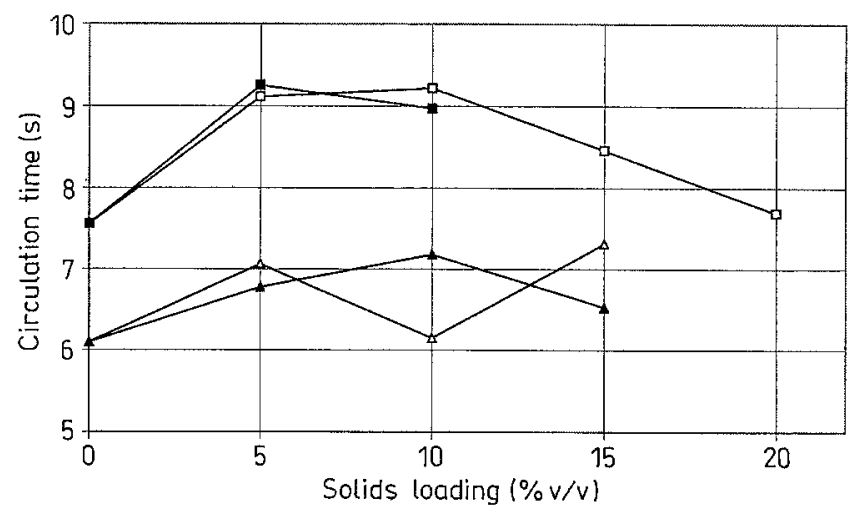

Fig. 8. Circulation time vs. solids loading for the draught tubes with a height of $0.42 \mathrm{~m}$ and different diameters, for the lower and higher specific gravity beads, with an air flow rate of $1.23 \mathrm{E}-5 \mathrm{~m}^{3} / \mathrm{s} .(\square$ $-\mathrm{Dr}=0.022 \mathrm{~m}, \mathrm{LB} ; \Delta-\mathrm{Dr}=0.032 \mathrm{~m}, \mathrm{LB} ; \mathbf{\square}-\mathrm{Dr}=0.022 \mathrm{~m}, \mathrm{HB}$; $\Delta-\mathrm{Dr}=0.032 \mathrm{~m}, \mathrm{HB})$

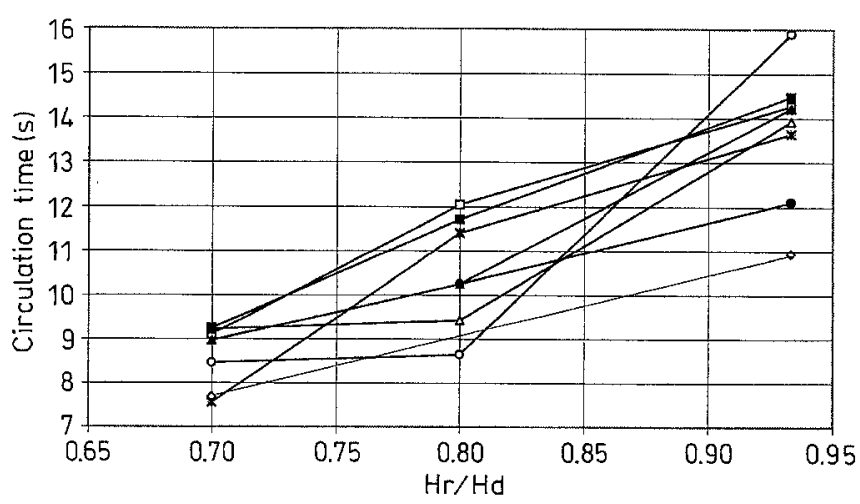

Fig. 9. Circulation time vs. the riser to down comer height ratio $(\mathrm{Hr} / \mathrm{Hd})$ for the draught tubes with a diameter of $0.022 \mathrm{~m}$, with different solids loading, for the lower and higher specific gravity beads, with an air flow rate of $1.23 \mathrm{E}-5 \mathrm{~m}^{3} / \mathrm{s}$. ( $X-0 \%$ solids; $\square-5 \%$ solids, $\mathrm{LB} ; \triangle-10 \%$ solids, LB; $O-15 \%$ solids, LB; $\diamond-20 \%$ solids, LB; $-5 \%$ solids, HB; $\Delta-10 \%$ solids, HB; - $15 \%$ solids, HB) 


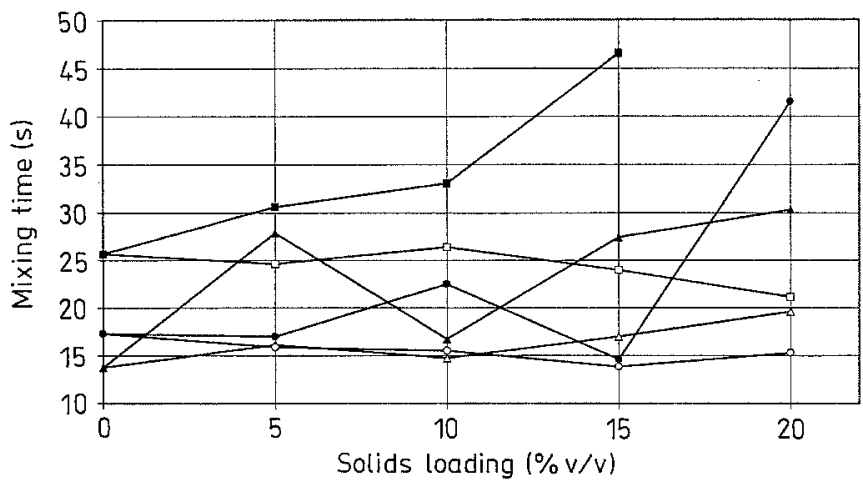

Fig. 10. Mixing time vs. solids loading for the draught tubes with a diameter of $0.032 \mathrm{~m}$ and different heights, for the lower and higher specific gravity beads, with an air flow rate of $1.23 \mathrm{E}-5 \mathrm{~m}^{3} / \mathrm{s}$.

$(\square-\mathrm{Hr}=0.42 \mathrm{~m}, \mathrm{LB} ; \triangle-\mathrm{Hr}=0.48 \mathrm{~m}, \mathrm{LB} ; \mathrm{O}-\mathrm{Hr}=0.56 \mathrm{~m}, \mathrm{LB}$;

- $\mathrm{Hr}=0.42 \mathrm{~m}, \mathrm{HB} ; \boldsymbol{\Lambda}-\mathrm{Hr}=0.48 \mathrm{~m}, \mathrm{HB} ;-\mathrm{Hr}=0.56 \mathrm{~m}, \mathrm{HB})$

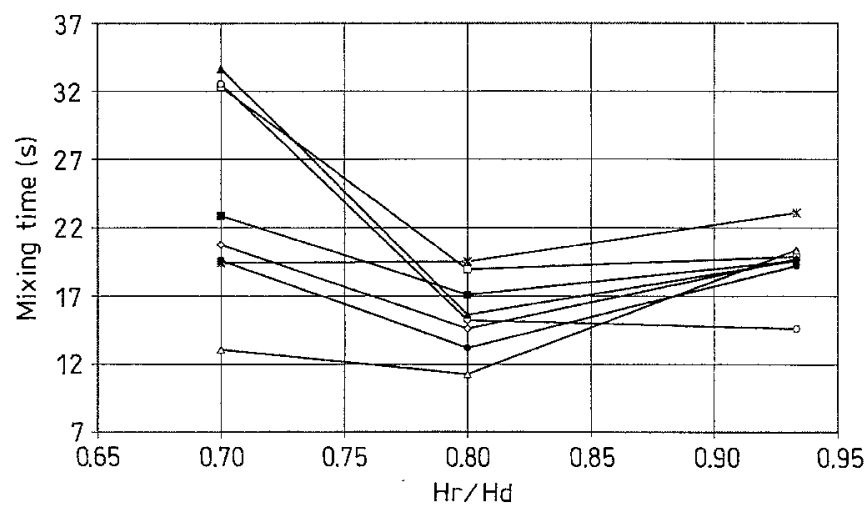

Fig. 11. Mixing times vs. the riser to down comer height ratio $(\mathrm{Hr} / \mathrm{Hd})$ for the draught tubes with a diameter of $0.022 \mathrm{~m}$, with different solids loading, for the lower and higher specific gravity beads, with an air flow rate of $1.23 \mathrm{E}-5 \mathrm{~m}^{3} / \mathrm{s}$. ( $X-0 \%$ solids; $\square-5 \%$ solids, $\mathrm{LB} ; \triangle-10 \%$ solids, $\mathrm{LB}$; $O-15 \%$ solids, $\mathrm{LB} ; \diamond-20 \%$ solids, $\mathrm{LB} ; \mathbf{\square}-5 \%$ solids, HB; $\boldsymbol{\Lambda}-10 \%$ solids, HB; $-15 \%$ solids, HB)

\section{3}

\section{Mixing time}

The results for the mixing time showed a significant variability (Fig. 10), which may be attributed to the (relatively) small size of the reactor and to the design of the degassing zone, at the top. Nevertheless, some comments are pertinent: The influence of the specific gravity is obvious for each draught tube. The data referring to the higher specific gravity beads show always higher mixing times than the data referring to the lower specific gravity beads; although not very clearly, a general ascending trend can be noticed, meaning that there is an increase of the mixing time with the solids loading.

Finally, Fig. 11 shows that the riser to down comer height ratio of 0.8 minimises the mixing time in this reactor for all the solids loading (the same kind of behaviour has been detected for the intermediate height draught tube).

\section{4}

\section{Conclusions}

The present study shows that the solids specific gravity influences the critical air flow rate and the mixing time in an internal loop airlift bioreactor, but does not affect significantly the circulation time.

It demonstrates that the critical air flow rate increases with an increase of the solids loading of the reactor; also the mixing time increases with the solids loading, while the circulation time shows a maximum between 5 and $10 \%(\mathrm{v} / \mathrm{v})$ solids.

Within the limits studied $(0.70-0.93)$, a rise in the riser to down comer height ratio corresponds to a decrease of the critical air flow rate and a rise in the circulation time. There is a minimum for the mixing time when that ratio equals 0.80 .

Also within the limits studied $(0.31-0.63)$, the critical air flow shows a minimum when the riser to down comer diameter ratio equals 0.46 , which is also the value that minimises the circulation time.

It can be concluded that the best mixing performances for a three phase internal loop airlift bioreactor are obtained for a riser to down comer diameter ratio of 0.46 and to a riser to down comer height ratio of 0.80 .

\section{References}

1. Choi, P.B.: Designing Airlift Loop Fermenters. Chem. Eng. December (1990) 32-37

2. Chen, N.Y.; Kondis, E.F.; Srinivasan, S.: Low Pressure Airlft Fermenter for Single Cell Protein Production: I. Design and Oxygen Transfer Studies. Biotechnol. Bioeng. 29 (1987) 414-420

3. Sousa, M.L.; Teixeira, J.A.; Mota, M.: Comparative Analysis of Ethanolic Fermentation in Two Continuous Flocculation Bioreactors and Effect of Flocculation Addition, Bioprocess Engng. 11 (1994) $83-90$

4. Tijuis, L.; Loosdrecht, M.C.M. van; Heijnen, J.J.: Formation and Growth of Heterotrophic Aerobic Biofilms on Small Suspended Particles in Airlift Reactors. Biotechnol. Bioeng. 44 (1994) 595-608

5. Siegel, Marc; Merchuk, J.C.: Hydrodynamics in Rectangular Airlift Reactors: Scale-up and the Influence of Gas-Liquid Separator Design. Can. J. Chem. Eng. 69 (1991) 465-473

6. Sukan, A.A.; Vardar-Sukan, F.: Mixing Performance of Airlift Fermenters Against Working Volume and Draft Tube Dimensions. Bioprocess Engng. 2 (1987) 33-38

7. Kennard, M.; Janekeh, M.: Two- and Three-Phase Mixing in a Concentric Tube Gas-Lift Fermentor. Biotechnol. Bioeng. 38 (1991) 1261-1270

8. Fraser, R.D.; Hill, G.A.: Hydrodynamic Characteristics of a Spining Sparger, External Loop Airlift Bioreactor. Can. J. Chem. Eng. 71 (1993) 419-425

9. Prasad, K.Y.; Ramanujam, T.K.: Liquid Circulation Velocity and Overall Gas Holdup in a Modified Jet Lop Bioreactor with Low SPECIFIC GRAVITY Particles. Bioprocess Engng. 10 (1994) 131-137

10. Merchuk, J.C.; Ladwa, N.; Cameron, A.; Bulmer, M.; Pickett, A.: Concentric-Tube Airlift Reactors: Effects of Geometrical Design on Performance. AIChE J. 40 (1994) 1105-1117

11. Moresi, M.: Optimal Design of Airlift Fermenters. Biotechnol. Bioeng. 23 (1981) 2537-2560

12. Siegel, M.H.; Merchuk, J.C.; Schugerl, K.: Airlift Reactor Analysis: Interrelationships Between Riser, Downcomer, and Gas-Liquid Separator Behavior, Including Gas Recirculation Effects. AIChE J. 32 (1986) $1585-1596$

13. Thomas, N.H.; James, D.A.: Fluid Dynamic Considerations in Airlift Bioreactors. Biotech. Proc. 60-71

14. Livingston, A.G.; Zhang, S.F.: Hydrodynamic Behaviour of ThreePhase (Gas-Liquid-Solid) Airlift Reactors. Chem. Eng. Sci. 48 (1993) 1641-1654

15. Siegel, M.H.; Hallaile, M.; Herskowitz, M.; Merchuk, J.C.: Hydrodynamics and Mass Transfer in a Three-Phase Airlift Reactor. In: R. King (ed.): 2 nd. International Conference on Bioreactor Fluid Dynamics, pp. $21-23,1988$ 
16. Weiland, P.: Influence of Draft Tube Diameter on Operation Behaviour of Airlift Loop Reactors. Ger. Chem. Eng. 7 (1984) 374-385

17. Favre, E.; Deront, M.; Péringer, P.: Influence of a Rotating Sieve on Pumping and Mixing Performances of an Internal Loop Reactor. Bioprocess Engng. 11 (1994) 91-95

18. Russel, A.B.; Thomas, C.R.; Lilly, M.D.: The influence of the Vessel Height and Top-Section Size on the Hydrodynamic Characteristics of Airlift Fermentors. Biotechnol. Bioeng. 43 (1994) 69-76

19. Lu, Wen-Jang; Hwang, Shyh-Jye: Liquid Mixing in Internal Loop Airlift Reactors. Ind. Eng. Chem. Research 33 (1994) 2180-2186
20. Assa, A.; Bar, R.: Biomass Axial Distribution in Airlift Bioreactor with Yeast and Plant Cells. Biotechnol. Bioeng. 38 (1991) $1325-1330$

21. Kawase, Y.; Omori, N.; Tsujimura, M.: Liquid-Phase Mixing in External Loop Airlift Bioreactors. J. Chem. Tech. Biotechnol. 61 (1994) $49-55$

22. Gianetto, A.; Ruggeri, B.; Specchia, V.; Sassi, G.; Forna, R.: Continuous Extraction Loop Reactor (CELR): Alcoholic Fermentation by Fluidized Entrapped Biomass. Chem. Eng. Sci. 43 (1988) 1891-1896 